\title{
Początki i rozwój szkolnictwa polskiego w Rumunii do 1939 roku
}

\begin{abstract}
Beginnings and development of Polish education in Romania until 1939
Poles settled in present-day Romania in the fourteenth century. A subsequent influx of Polish settlers followed the fall of the Kościuszko Uprising. The aim of this study is to present the history of education in the Polish minority in Romania. The work focuses on showing various forms of educational and upbringing institutions from the early $19^{\text {th }}$ century to 1939 . In the analyzed period, the Poles organized mainly kindergartens and comprehensive primary and secondary schools in Bukowina (now northern Romania). They also made attempts at introducing the Polish language to teachers' training institutions i.e. teachers' training colleges for men and women. They established their own socio-educational societies and built Polish Houses in which they pursued a wide range of educational and cultural activities. In the Kingdom of Romania, Polish children could also attend (under certain conditions) Polish language classes in Romanian state schools. Owing to the Polish Schools in Romania, followed by the Polish School Association in Romania, Polish private education assumed various forms.
\end{abstract}

Keywords: Polish education, Bukowina, Romania, Polish School Association in Romania, Polish Schools in Romania

\section{Wprowadzenie}

Polacy pojawili się na terenach ówczesnej Rumunii w połowie XIV w., za czasów panowania Kazimierza Wielkiego. Zajęli Ziemię Szczypińską, teren położony na północnej Bukowinie. Na mocy traktatu polsko-węgiersko-mołdawskiego z lat 1498-1499 utracili tę ziemię na rzecz Mołdawii. W kolejnych wiekach Polska rywalizowała z Węgrami, potem Turcją, a od końca XVII w. z Habsburgami, a potem carami rosyjskimi o zwierzch- 
nictwo nad Mołdawią. Od początku istnienia księstwa Mołdawii, stosunki polityczne, gospodarcze i kulturalne między Mołdawią a Polską były ożywione, zwłaszcza na terenie przygranicznym i tranzytowym, który to stanowiła Bukowina. Nowa fala Polonii bukowińskiej pojawiła się w okresie porozbiorowym.

Bukowina w 1774 roku została zajęta przez Austrię. Od 1 lutego 1787 r. na mocy zarządzenia cesarza Józefa II Bukowina została przyłączona do Galicji jako obwód (cyrkuł) i podlegała gubernium we Lwowie. Na jej czele stał starosta rezydujący w Czerniowcach (ukr. Чернівці). W czasach austriackich na terenie Bukowiny osiedlali się Polacy pochodzący głównie $\mathrm{z}$ emigracji zarobkowej, ale też i emigracji politycznej. Wspomnieć należy też o urzędowym przesiedlaniu górników polskich z Bochni, Kałusza i Wieliczki na tereny południowej Bukowiny do miejscowości Kaczyka (rum. Cacica). Na początku XIX w. Bukowinę zasiedlali górale czadeccy oraz kolejarze do pracy przy budowie i otwarciu linii kolei Lwów-Czerniowce.

W 1849 r. Bukowina przez oddzielenie jej od Galicji stała się księstwem z osobną administracją i autonomią, a nawet od 1860 r. z własnym herbem i rządem krajowym, na czele którego stał gubernator ${ }^{1}$. Jednak zaznaczyć należy, że w niektórych gałęziach administracji Bukowina była związana z Galicją do 1918 r. Na czele rządu krajowego Bukowiny stał prezydent kraju mianowany przez cesarza i podlegał on centralnemu rządowi w Wiedniu. Prezydent Bukowiny pełnił jednocześnie funkcję przewodniczącego Rady Szkolnej Krajowej ${ }^{2}$. Królestwo Bukowiny było podzielone na 11 powiatów (Gura Humorului, Kimpulung33, Kocmań, Radowce, Seret, Storożyniec, Suczawa, Waszkowce, Wyżnica i Zastawna oraz jedno miasto wydzielone Czerniowce z charakterem powiatu). W 1918 r. Bukowina została wcielona do Rumunii. W obszar Wielkiej Rumunii weszły też Besarabia, część Banatu i Południowa Dobrudża

Polacy na Bukowinie, a potem w Królestwie Rumunii stanowili mniejszą liczebnie w stosunku do Ukraińców, Rumunów, Żydów i Niemców narodowość. Według spisu z 1910 r. znajdowali się na 5 miejscu za wspomnianymi wyższej narodowościami, a przed Węgrami, Rosjanami, Czechami, Słowakami, Ormianami, Cyganami. Po I wojnie światowej wielu Polaków powróciło do kraju. Z samej Bukowiny [...] wyjechało ok. 5 tys. osób, wśród nich było wielu reprezentantów elit, co znaczaco osłabiło polski ruch narodowy $y^{5}$ Stąd według spisu z 1930 r., na obszarze Wielkiej Rumunii, Polacy stanowi-

\footnotetext{
1 I. Nistor, Istoria Bucovinei, București 1991, s. 107-116.

2 E. Biedrzycki, Historia Polaków na Bukowinie, Warszawa - Kraków 1973, s. 23-24.

${ }^{3}$ Dziś rumuńska nazwa tej miejscowości to Câmpulung Moldovenesc.

${ }^{4}$ J. Demel, Historia Rumunii, wyd. II poprawione i uzupełnione, Wrocław-Warszawa-Kraków-Gdańsk-Łódź 1986, s. 358-359, 386-387.

${ }^{5}$ K. Nowak, Problemy szkolnictwa polskiego w Rumunii oraz Mołdawii dawniej i wspótcześnie, ,Rocznik Stowarzyszenia Naukowców Polaków Litwy” 2017, t. 17, s. 235.
} 
li 100 tys. mieszkańców, co oznaczało, że reprezentują najmniejszą liczebnie mniejszość narodową ${ }^{6}$.

Biorąc pod uwagę szkolnictwo na Bukowinie, to monarchia austriacka w połowie XVIII w. zaczęła przejmować sprawy edukacyjne pod kontrolę administracji. W $1760 \mathrm{r}$. w Wiedniu powstała Nadworna Komisja Naukowa (Studienhofkommission), której zadaniem był nadzór nad oświatą. Realizację tego zadania miały wspierać tworzone w prowincjach krajowe komisje szkolne, a w guberniach referaty do spraw szkolnych. W Galicji komisja szkolna powołana została w 1776 r. W 1778 r. Nadworna Komisja Naukowa została wcielona do Kancelarii Nadwornej (Hofkanzlei) ${ }^{7}$. Cesarz Józef II wprowadził język niemiecki jako urzędowy, co przyczyniło się do zniesienia równouprawnienia łaciny i języka polskiego. Organizował szkolnictwo. W 1784 r. na Bukowinę sprowadzono nauczycieli i otwarto dwie 4-klasowe szkoły główne tzw. Hauptschulen, jedną w Czerniowcach a drugą w Suczawie. Były to szkoły dwujęzyczne niemiecko-rumuńskie. Po przyłączeniu Bukowiny do Galicji nadzór nad szkołami przejęło Gubernium we Lwowie. Od 1815 r. sprawami szkolnictwa zajmował się lwowski rzymskokatolicki konsystorz, a od 1851 r. prawosławny konsystorz biskupi w Czerniowcach. W latach 1860-1867 austriackie Ministerstwo Oświecenia Publicznego, potem Wyznań i Oświecenia powołane w 1848 roku w miejsce Nadwornej Komisji Edukacyjnej, wcielono do Ministerstwa Stanu, potem je reaktywowano. W gestii Ministerstwa znajdowały się: a) agendy państwowego zarzadu duchownego, b) najwyższe kierownictwo i nadzór wszystkich gatęzi nauczania $i$ wychowania, c) popieranie nauk $i$ umiejętności $i^{8}$. Reformy szkolnictwa $\mathrm{z}$ lat 1868-1873 powierzyły nadzór nad szkolnictwem urzędnikom świeckim. Z budżetu krajowego utrzymywano gminne szkoły ludowe, tylko szkoły czerniowieckie finansował budżet miasta. W 1869 r. frekwencja dzieci w szkołach bukowińskich była następująca: 9,62\% dzieci narodowości niemieckiej, 5,87\% dzieci narodowości polskiej, 4,08\% dzieci narodowości węgierskiej, $1,05 \%$ dzieci narodowości ukraińskiej, $1 \%$ dzieci narodowości żydowskiej i rumuńskiej. Pod koniec XIX w. na Bukowinie wskaźnik skolaryzacji dzieci objętych obowiązkową nauką osiągnął prawie $70 \%{ }^{9}$. Po I wojnie światowej na całym terytorium Wielkiej Rumunii wprowadzono język rumuński jako rządowy. Zarządzeniem z 1922 r. rozpoczęła się rumunizacja szkolnictwa mniejszości narodowych w Królestwie Rumunii.

Celem niniejszego studium jest prezentacja dziejów szkolnictwa dla mniejszości polskiej na terenie dzisiejszej Rumunii w okresie od początków XIX w. do 1939 r., ze

\footnotetext{
${ }^{6}$ W. Sworakowski, Mniejszości narodowe w Rumunji wobec programu rzadowego, „Sprawy Narodowościowe" 1930, nr 5-6, s. 658.

7 S. Salmonowicz, Podstawy prawne funkcjonowania Komisji Edukacji Narodowej, „Rozprawy z Dziejów Oświaty", 1980, nr 23, s. 43.

${ }^{8}$ D. Lewandowska, C. K. Ministerstwo Wyznań i Oświaty 1848-1918, Archiwum Główne Akt Dawnych w Warszawie, https://www.archivesportaleurope.net/ead-display/-/ead/pl/aicode/PL-1/type/fa/id/PL-1-304_ SLASH_0;jsessionid=C298A68029531A0119BCC1A9E3EBCFFD, [dostęp: 10.02.2018].

${ }^{9}$ E. Biedrzycki, op. cit., s. 102-103.
} 
szczególnym uwzględnieniem szkolnictwa dla Polonii bukowińskiej. Szkolnictwo polskie w Rumunii, pomimo sukcesów i porażek, uwarunkowane przede wszystkim czynnikami politycznymi, demograficznymi i społecznymi rozwija się już dwa wieki. Do jego chlubnych tradycji nawiązują współczesne szkoły np. Szkoła Podstawowa i Przedszkole nr 2 im. Krystyny Bochenek w Pojanie Mikuli (rum. Poiana Micului) oraz Szkoła Podstawowa im. Henryka Sienkiewicza w Nowym Sołońcu (rum. Soloneţu Nou). W tych szkołach wciąż prowadzone są lekcje języka polskiego ojczystego ${ }^{10}$.

W niniejszym szkicu wykorzystano opracowanie Emila Biedrzyckiego oraz materiał archiwalny zgromadzony w Archiwum Akt Nowych w Warszawie. Nazwy miejscowości podane zostały w oryginalnym brzmieniu materiałów źródłowych.

\section{Początki szkolnictwa dla mniejszości polskiej na Bukowinie}

Szkolnictwo polskie na ziemiach rumuńskich zaczęło się rozwijać w XIX w., głównie na terenie Bukowiny, gdyż tam było największe skupisko mniejszości polskiej.

Z dotychczasowych ustaleń wynika, że pierwsza szkoła, w której uczono języka polskiego znajdowała się we wsi Kaczyka, w której przy zakładaniu kopalni soli pracowali polscy górnicy i urzędnicy. Kopalnia została uruchomiona w 1791 r. Od początków XIX w. kopalnia posiadała swoja szkołe, w której uczyli nauczyciele znający trzy języki pracowników kopalni, mianowicie niemiecki, rumuński $i$ właśnie język polski ${ }^{11}$. W kaczyckiej szkole w 1816 r. uczył niejaki Żurowski. Rok wcześniej w Czerniowcach otwarto pierwszą szkołę dla dziewcząt, w której pracowały nauczycielki znające język niemiecki, polski i co najmniej jedna język mołdawski (rumuński) ${ }^{12}$.

W okresie formowania się autonomii Księstwa Bukowiny, choć zaczęła się na Bukowinie szerzyć niemczyzna, która znajdowata korzystne warunki rozwoju w niemieckich szkołach $i$ w niemieckim wyłącznie języku urzędowym, [...] żywioł ten [polski], prześladowany przez Rumunów i sprzymierzonych z nimi Niemców, pozbawiony wszelkich praw narodowych, nie tylko ostat się własna sita, lecz nawet wzmacniat się i potężnia ${ }^{13}$. Dla przykładu warto wymienić szkoły trywialne w Serecie i w Radowcach, gdzie w latach 50. XIX w. język polski, zaraz po języku niemieckim, był językiem obowiązkowym ${ }^{14}$. W 1860 r. w Kocmaniu funkcjonowała szkoła z oddziałem niemieckim i oddziałem polsko-ukraińskim. W tym czasie, w Królestwie Bukowiny, rosła liczba szkół bądź wyłącznie polskich, bądź też mieszanych z językiem polskim jako

\footnotetext{
${ }^{10}$ M. Radziszewska, Wyjazd studyjny polskich historyków wychowania do Rumunii, „Biuletyn Historii Wychowania" 2017, nr 37, s. 171-172.

${ }^{11}$ A. Szewczyk, Jest takie miejsce ... Kaczyka na Bukowinie, „Wiadomości Bocheńskie” 2015, nr 4, s. 37.

12 E. Biedrzycki, op. cit., s. 101.

13 G. Smólski, Polacy na Bukowinie, „Nowa Reforma” 1906, nr 234 z 14 października, s. 1.

${ }^{14}$ W. Sworakowski, Polskie szkolnictwo prywatne w Rumunii, „Sprawy Narodowościowe” 1931, nr 1, s. 67.
} 
obowiązkowym ${ }^{15}$. Na przykład we wsi górali z Czadeckiego w Nowym Sołońcu, w 2-klasowej szkole uczył nijaki Mistalski z pochodzenia Litwin. Sołoniecka szkoła trywialna podlegała metropolitalnemu konsystorzowi lwowskiemu, a szczególna troska i nadzór nauczania spoczywat na kaczyckim proboszczu, który był jednocześnie przewodniczacym Rady Szkolnej ${ }^{16}$. Mistelski nie sprawdził się jako nauczyciel, na jego miejsce dzięki wsparciu Towarzystwa Polskiej Bratniej Pomocy z siedzibą w Czerniowcach ${ }^{17}$, delegowano do wsi polskiego nauczyciela Daniela Mielnika, który w 1870 r. rozpoczął nauczanie języka polskiego w Nowym Sołońcu i uczył go aż przez 40 lat, do przejścia na emeryturę ${ }^{18}$. Należy zaznaczyć, że potrzebę organizacji szkół polskich na Bukowinie zahamowała najpierw ustawa państwowa (1868), następnie ustawa krajowa (1873). Zmiany dotyczyły m.in. przeniesienia nadzoru nad szkolnictwem z rąk władzy duchownej na świecką. Reorganizacja szkół ludowych połączona z germanizacją Bukowiny przyczyniła się do systematycznego usuwania języka polskiego ze szkół. Język polski wyeliminowano ze szkół w miejscowościach Stara Huta, Suczawa, Seret, Sadagóra, Rohoźno, Żuczka, Panka a także czerniowieckich seminariów nauczycielskich ${ }^{19}$. Jednak Polacy nie pozostali bierni. Wnosili petycje do władz o przywrócenie w szkołach języka polskiego. Apelowali też na łamach gazet m.in. czerniowieckiej „Gazety Polskiej”, „Kuriera Lwowskiego”. Ich wysiłki stały się skuteczne, gdyż m.in. w 1890 r. Krajowa Rada Szkolna zarządziła rozpoczęcie nauki języka polskiego w szkole w Sadagórze, a w 1896 r. w szkole w Żuczce ${ }^{20}$.

Istotny wkład w rozwój polskiego szkolnictwa na Bukowinie wniosło powstałe w $1891 \mathrm{r}$. galicyjskie Towarzystwo Szkoły Ludowej (TSL) ${ }^{21}$. Bukowina terytorialnie przynależała do Kołomyjskiego Związku Okręgowego, i na jej terenie jako jedne z pierwszych powstały Koła TSL w Czerniowcach i Suczawie. Podjęły ono energiczną akcję wśród ludności polskiej, co skutkowało zabieganiem u władz austriackich o zakładanie publicznych szkół ludowych z polskim językiem wykładowym ${ }^{22}$. Jednak pod wpływem sprzeciwu czynników niemieckich, TSL tworzyło tylko szkoły prywatne. W roku szkolnym 1904/1905 TSL uruchomiło 23 szkoły prywatne, w tym aż $9 \mathrm{z}$ nich funkcjonowało w Czerniowcach ${ }^{23}$. TSL na

15 E. Biedrzycki, op. cit., s. 105-106.

${ }^{16}$ A-E. Zelionca, Nowy Sołoniec. Dzieje wsi i parafii, Suceava 2014, s. 83.

17 Towarzystwo Polskie Bratniej Pomocy powołano 16 marca 1869 roku w Czerniowcach. W. Ćwiek, Przeszłość Towarzystwa polskiego bratniej pomocy i Czytelni polskiej, Czerniowce 1995, s. 13-14.

18 A-E. Zelionca, Nowy Soloniec, s. 85.

${ }^{19}$ Chodzi o męskie seminarium nauczycielskie założone w 1870 r. oraz seminarium nauczycielskie dla dziewcząt, zorganizowane przez ss. Rodziny Marii w 1873 r. jako polska szkoła żeńska z internatem.

${ }^{20}$ E. Biedrzycki, op. cit., s. 106 i 109-110 i 118-119.

${ }_{21}$ M. Stępowski, Towarzystwo Szkoły Ludowej: jak powstało, co zrobiło i do czego dąży: w 20-ta rocznice powstania Towarzystwa, Kraków 1911, s. 17.

22 W. Sworakowski, Polskie szkolnictwo prywatne..., s. 67.

${ }^{23}$ Archiwum Akt Nowych w Warszawie (dalej AAN), zespół: Ministerstwo Spraw Zagranicznych (dalej MSZ), sygn. 10752, Dopełnienie do Raport wicekonsula Tadeusza Kijeńskiego pt. Szkolnictwo polskie na Bukowinie na tle szkolnictwa mniejszościowego, Czerniowce dn. 28.03.1930, k. 64. 
Bukowinie opłacało wędrownych nauczycieli za udzielanie prywatnej nauki oraz rozdawało bezpłatnie egzemplarze elementarza ${ }^{24}$.

Poza szkołami prywatnymi, w oparciu o austriacką ustawę krajową z 1873 r. do 1909 r. na Bukowinie język polski był wykładany jako przedmiot trzy razy w tygodniu w ludowych szkołach państwowych. Oprócz Czerniowiec i Nowego Sołońca, takie szkoły mieściły się w miejscowościach takich, jak: Kaczyka, Kocmań, Plesza, Pojana Mikuli, Solka, Hliboka, Zadowa, Panka, Laurenta, Dunawiec ${ }^{25}$. Staraniem Koła TSL w Suczawie, język polski był udzielany w miejscowej szkole ludowej oraz w wiejskich szkółkach w Rudzie oraz Dawidendach Zrebie ${ }^{26}$. Warto dodać, że rząd zakładając szkoły powszechne dla Ukraińców, Rumunów, Niemców i Żydów, zezwolił również Polakom utworzyć przy szkołach niemieckich dwie najniższe klasy z językiem wykładowym polskim. Z każdym następnym rokiem szkolnym dodawano kolejne klasy, i tak w 1913 r. funkcjonowało już 36 szkół powszechnych, które miały nawet pięć i sześć klas polskich ${ }^{27}$. Natomiast zupełnie wyodrębnienie klas polskich w odrębne szkoły polskiej nastąpiło na wniosek inspektora szkolnego Adolfa Mitelskiego dopiero pod koniec I wojny światowej ${ }^{28}$.

\section{Szkolnictwo polskie w Wielkiej Rumunii}

Po I wojnie światowej doszło do zjednoczenia Rumunii. W jej obszar wcielono Bukowinę i Besarabię, tereny na których prowadzono szkolnictwo polskie oraz Siedmiogród, część Banatu i Południową Dobrudżę ${ }^{29}$. Powstała Wielka Rumunia - „România Mare”. Bukowina utraciła autonomię zdobytą w Austrii, a Polonia swojego reprezentanta w dwuizbowym parlamencie. Sprawy Polonii w Rumunii na Bukowinie reprezentowała Polska Rada Narodowa (1918-1925) ${ }^{30}$. Natomiast w Besarabii był to Związek Polski, utworzony 9 września 1929 r. z siedzibą w Akermanie ${ }^{31}$.

${ }^{24}$ M. Stępowski, op. cit., s. 80-81.

25 AAN, zespół: MSZ, sygn. 10752, Dopełnienie do Raport wicekonsula Tadeusza Kijeńskiego pt. Szkolnictwo polskie na Bukowinie na tle szkolnictwa mniejszościowego, Czerniowce dn. 28.03.1930, k. 64.

${ }^{26}$ M. Stępowski, op. cit., s. 81.

27 AAN, zespół: MSZ, sygn. 10752, Dopełnienie do Raport wicekonsula Tadeusza Kijeńskiego pt. Szkolnictwo polskie na Bukowinie na tle szkolnictwa mniejszościowego, Czerniowce dn. 28.03.1930, k. 64-65.

${ }^{28}$ AAN, zespół: MSZ, sygn. 10752, Opracowanie wicekonsula Tadeusza Kijeńskiego pt. Szkolnictwo polskie na Bukowinie na tle szkolnictwa mniejszościowego, Czerniowce dn. 24.01.1930, k. 12.

29 J. Demel, op. cit., s. 358-359, 386-387, A. Cioroianu, Piękne początki, w: Łacińska wyspa. Antologia rumuńskiej literatury faktu. Wybór, opracowanie i komentarze Bogumił Luft, Warszawa 2018, s. 16.

${ }^{30}$ Polska Rada Narodowa powstała w 1918 r. z przekształcenia bukowińskiego Koła Polskiego. K. Nowak, Polskie życie organizacyjne w Rumunii do 1989 roku, w: Związek Polaków w Rumunii 1990-2010, opracowanie i korekta S. Iachimovschi, E. Wieruszewska-Calistru, Suceava 2010, s. 009; K. Dopierała, Społeczność polska na Bałkanach Rumunia, Bułgaria, Jugosławia, w: Polonia w Europie, (red.) B. Szydłowska-Ceglowa, Poznań 1992, s. 658.

31 K. Dopierała, op. cit. 
W pierwszych latach po zjednoczeniu, szkolnictwo polskie w Królestwie Rumunii funkcjonowało bez przeszkód, gdyż rząd rumuński przejąt polskie szkolnictwo austriackie i niektóre szkoły TSL $i$ do roku 1923 odnosit się do rozwoju szkót powszechnych ze względna tolerancja ${ }^{32}$. Nawet w Besarabii przed 1923 r. polskie szkoły w Kiszyniowie, Bielcach, Elizabetówce, Benderach i Krycojach częściowo finansowano z rumuńskich funduszy państwowych. Działalność oświatową wspierały materialnie też podmioty społeczne i prywatne. Dzięki temu na Bukowinie, do 1923 r., udało się zorganizować nauczanie 2685 dzieci w szkołach odrębnych oraz w klasach z językiem wykładowym polskim, gdzie język rumuński prowadzony był jako przedmiot, w różnych miejscowościach. Były to: Czerniowce (4 szkoły z 1129 uczniów), Bojany (1 szkoła 92 uczniów), Sadagóra (1 szkoła 139 uczniów), Storożyniec (1 szkoła 170 uczniów), Laurenka (1 szkoła 73 uczniów), Kaczyka (3 klasy z 136 uczniów), Nowy Sołoniec (3 klasy z 122 uczniów), Wyżnica (2 klasy z 82 uczniami), Waszkowce (2 klasy z 132 uczniami), Dawideny-Zręb (1 klasa 71 uczniów), Dunawiec (1 klasa 76 uczniów), Zadowa (1 klasa 75 uczniów), Kocmań (1 klasa 74 uczniów), Hliboka (1 klasa 62 uczniów), Seret (1 klasa 65 uczniów), Baniłów Ruski (1 klasa 49 uczniów), Zastawna (1 klasa 63 uczniów), Pojana Mikuli (1 klasa 75 uczniów) ${ }^{33}$.

Rozwój szkolnictwa polskiego w Wielkiej Rumunii przerwany został reorganizacją szkolnictwa w tym kraju. W 1922 r. zarządzeniem władz rumuńskich rozpoczęła się rumunizacja szkolnictwa mniejszości narodowych ${ }^{34}$. Rumuński język wykładowy wprowadzono do wszystkich typów szkół publicznych. Natomiast wszystkie nierumuńskie szkoły prywatne upaństwowiono i zrumunizowano. Dzieci i młodzież polską pozbawiono nauki języka polskiego, gdyż nastąpiło zamknięcie szkół polskich z dniem 1 września $1922 \mathrm{r}^{35}$ Teoretycznie pozostawiono wykład religii $\mathrm{w}$ języku polskim, ale tylko tam, gdzie był ksiądz Polak lub odpowiednia siła nauczycielska ${ }^{36}$. Wobec nauczycieli polskich zastosowano przesunięcia do innych miejscowości, najczęściej w głąb Rumunii i zastępowanie ich nauczycielami nieznającymi języka polskiego. Od polskich nauczycieli żą-

\footnotetext{
32 AAN, zespół: MSZ, sygn. 10752, Opracowanie wicekonsula Tadeusza Kijeńskiego pt. Szkolnictwo polskie na Bukowinie na tle szkolnictwa mniejszościowego, Czerniowce dn. 24.01.1930, k. 12.

33 AAN, zespół: MSZ, sygn. 10752, Opracowanie wicekonsula Tadeusza Kijeńskiego pt. Szkolnictwo polskie na Bukowinie na tle szkolnictwa mniejszościowego, Czerniowce dn. 24.01.1930, k. 13.

${ }^{34}$ W Wielkiej Rumunii problem mniejszości w świadomości władz stał się niezwykle dokuczliwy po włączeniu w granice państwa nowych obszarów - wraz z inkorporacją Bukowiny w Rumunii zwiększyła się liczba Niemców i Ukraińców, Besarabii - Rosjan, a Siedmiogrodu - Węgrów. Pierwsze rządy nie potrafiły sobie z tym poradzić. Premier Ion I.C. Brătianu traktował mniejszości jak obywateli „drugiej kategorii”, szczególnie zaś wrogo odnosił się do Węgrów. A. Sylburska, Kwestia mniejszości węgierskiej w Czechosłowacji, Rumunii i Jugosławii w okresie międzywojennym na łamach ,,Spraw Narodowościowych” (1927-1939), „Acta Universitatis Lodziensis Folia Historica” 2014, nr 92, s. 155.

${ }^{35}$ AAN, zespół: MSZ, sygn. 10752, Dopełnienie do Raport wicekonsula Tadeusza Kijeńskiego pt. Szkolnictwo polskie na Bukowinie na tle szkolnictwa mniejszościowego, Czerniowce dn. 28.03.1930, k. 66.

${ }^{36}$ AAN, zespół: MSZ, sygn. 10752, Opracowanie wicekonsula Tadeusza Kijeńskiego pt. Szkolnictwo polskie na Bukowinie na tle szkolnictwa mniejszościowego, Czerniowce dn. 24.01.1930, k. 13.
} 
dano dodatkowych egzaminów z języka rumuńskiego, które należało zdać w bardzo krótkim czasie. Takie działania przyczyniły się do emigracji nauczycieli polskich z Rumunii do Polski ${ }^{37}$.

Tymczasem w Wielkiej Rumunii przystąpiono do rozbudowy sieci szkolnictwa wszystkich szczebli. W 1924 r. na mocy ustawy przedłużono obowiązek nauki z 4 do 7 lat szkoły powszechnej ${ }^{38}$. Art. 7 Ustawy o publicznym szkolnictwie powszechnym z 1924 r. $^{39}$ oraz regulamin publicznego szkolnictwa powszechnego regulował kwestie języka mniejszości w szkole. W myśl powyższych przepisów władze rumuńskie zezwalały na naukę języka polskiego kilka godzin tygodniowo w szkole, gdzie było 40 dzieci polskich. Z tego przywileju skorzystały dzieci polskie w Czerniowcach i w licznych miejscowościach na prowincji. Jednak stopniowo te formy nauki języka polskiego likwidowano, a ostatecznie w 1926 r. zaprzestano lekcji języka polskiego w Nowym Sołońcu, Sadagórze, Pojanie-Mikuli, Pleszy i Rudzie ${ }^{40}$. Nie zabrakło zdecydowanego stanowiska Polonii w żądaniach prowadzenia nauki języka polskiego w szkołach rumuńskich. Rodzice dzieci szkolnych wszczynali strajki, mające na celu zablokowanie ustawy o likwidacji lekcji języka polskiego w szkole ${ }^{41}$.

Zmiany w szkolnictwie polskim w Wielkiej Rumunii przyniosła dopiero podpisana przez Ministra Oświaty dr. Constantina Angelescu ${ }^{42}$ Ustawa o nauce prywatnej z 22 grudnia 1925 r. Ten akt prawny nadawał specjalnym instytucjom szkolnym uprawnienia do organizowania prywatnych szkół mniejszościowych, w tym ochronek, szkół powszech-

37 W. Sworakowski, Polskie szkolnictwo prywatne..., s. 73.

38 J. Demel, op. cit., s. 394.

${ }^{39}$ Art. 7 i 52 Ustawy o szkolnictwie powszechnym z dnia 24 czerwca 1924 r. ogłoszonej w Monitorze Oficjalnym Nr 161 z dnia 26 czerwca 1924 r. AAN, zespół: MSZ, sygn. 10752, Dopełnienie do Raport wicekonsula Tadeusza Kijeńskiego pt. Szkolnictwo polskie na Bukowinie na tle szkolnictwa mniejszościowego, Czerniowce dn. 28.03.1930, k. 66.

40 AAN, zespół: MSZ, sygn. 10752, Opracowanie wicekonsula Tadeusza Kijeńskiego pt. Szkolnictwo polskie na Bukowinie na tle szkolnictwa mniejszościowego, Czerniowce dn. 24.01.1930, k. 13.

${ }^{41}$ Opór rodziców egzemplifikuje poniższy fragment. Otóż mieszkańcy Pleszy, którzy sprzeciwiając się ustawie o likwidacji lekcji języka polskiego w szkole rozpoczęli w 1927 r. dtugotrwaty strajk, polegajacy na zatrzymaniu dzieci $w$ domach. Pleszanie nie ugięli się pod presja władz rumuńskich, które naktadały na rodziców mandaty i zagrażały pozbawieniem wolności. Stojąc $w$ obronie nauczania $w$ języku polskim, niektórzy trafili do aresztu, zaś jeden z mieszkańców został tak dotkliwie pobity, że do zdrowia wracal przez długi czas. Nieugięta postawa polskich górali wpisała się w ogólne przeciwstawienie się Polaków wobec polityki rumunizacyjnej, co wkrótce doprowadziło do tego, że z początkiem roku szkolnego 1931-1932 lekcje w języku polskim zostaty przywrócone. A-E. Zelionca, Plesza. Dzieje wsi i parafii, Suceava 2016, s. 37.

${ }^{42}$ Constantin Angelescu (1869-1948) - rumuński minister oświaty w latach 1918-1933 oraz w latach 1934-1938. P. Gołdyn, Wizyta ministra oświaty Rumunii Constantina Angelescu w Polsce w 1937 r. w świetle ówczesnych doniesień prasowych, w: W kręgu polsko-rumuńskiej wspótpracy oświatowej w pierwszej połowie $X X$ wieku. Wybrane aspekty /Aspecte ale colaborării polono-române în domeniul educaţiei în prima jumătate a secolului al. XX-lea/, Poznań-Kalisz 2017, s. 13-14. M. Radziszewska, Stan prywatnego szkolnictwa polskiego $w$ Królestwie Rumunii $i$ w rejencji olsztyńskiej Prus Wschodnich na kanwie wizyty rumuńskiego ministra oświaty Constantina Angelescu w Polsce w 1937 roku, w: Historia i dzień dzisiejszy w relacji polsko-rumuńskich, opracowanie redakcyjne i korekta tekstów polskich K. Stempel-Gancarczyk, E. Wieruszewska-Calistru, Suceava 2017, s. 114-128. 
nych oraz szkół średnich. Władze rumuńskie zezwalały na prowadzenie nauki na poziomie średnim w klasach o co najmniej 10 uczniach, zaś edukacja elementarna miała być prowadzona dla minimum 20 dzieci w szkole ${ }^{43}$. Natomiast polska mniejszość nie miała możliwości otwierania prywatnych seminariów nauczycielskich oraz szkół o typie uniwersyteckim. W ten sposób ustawodawca pozbawił Polaków kształcenia własnych nauczycieli ${ }^{44}$. Uruchomienie prywatnej szkoły mniejszościowej w Rumunii wiązało się najpierw z uzyskaniem przez specjalne instytucje osobowości prawnej, następnie specjalnych zaświadczeń od rumuńskiego Ministerstwa Oświaty. Najszybciej powyższe wymogi spełniły „Gminy Polskie” w Besarabii oraz Towarzystwo Polskie im. Adama Mickiewicza w Bukareszcie. Problem pojawił się na Bukowinie, gdyż wobec rozwiązania przez władze rumuńskie wszystkich kół Towarzystwa Szkoły Ludowej, nie było instytucji, która by zajęła się polską akcją oświatową na tym terenie ${ }^{45}$. Działacze bukowińscy potrzebowali czasu, aby doprowadzić do powstania instytucji oświatowej.

W dniu 1 listopada 1927 r., staraniem adwokata dra Grzegorza Szymonowicza, powołano Polską Macierz Szkolną w Rumunii (PMSwR) z siedzibą w Czerniowcach ${ }^{46}$. Było to społeczne towarzystwo oświatowe, które korzeniami sięgało PSM utworzonej 28 kwietnia 1905 r. w Warszawie. Początkowo zasięg terytorialny Macierzy obejmował teren Królestwa Polskiego, jednak po odzyskaniu przez Polskę niepodległości objął on też województwa centralne oraz wschodnie. W okresie międzywojennym Macierz postrzegano jako krzewicielkę oświaty i kultury polskiej, godna spadkobierczynię ideałów pozytywistycznych ${ }^{47}$. Krzewienie oświaty w duchu chrześcijańskim i narodowym odbywało się głównie przez zakładanie, utrzymanie i popieranie instytucji oświatowo-wychowawczych. Stąd też czerniowiecka PSMwR już w roku szkolnym 1928/29 otworzyła dwie ochronki w Czerniowcach i Sadagórze oraz szkoły w Czerniowcach. Była to 4-klasowa szkoła powszechna i szkoła przemysłowo-dokształcająca ${ }^{48}$. W kolejnych latach funkcjonowania, które splotły się z reorganizacją rumuńskiego szkolnictwa średniego, w tym z naciskiem na szkoły zawodowe, rozszerzono zasięg oddziaływania PMSwR na Besarabię, Siedmiogród oraz Mołdawięę․ Według stanu z 1 grudnia 1929 r. PSMwR utrzymywała jedno 4-letnie gimnazjum jako szkołę średnią, jedną szkołę zawodową uzupełniającą, 7 szkół powszechnych, a przy nich 3 ochronki i 15 kursów języka polskiego.

${ }^{43}$ AAN, zespół: MSZ sygn. 10752, Ustawa o nauce prywatnej. Tłumaczenie z języka rumuńskiego, k. 26-48.

${ }^{44}$ W. Sworakowski, Polskie szkolnictwo prywatne w Rumunii (dokończenie), „Sprawy Narodowościowe” 1931, nr 2-3, s. 239-240.

45 W. Sworakowski, Polskie szkolnictwo prywatne..., s. 74.

${ }^{46}$ K. Dopierała, op. cit., s. 661.

${ }^{47}$ H. Markiewicz, Rzecz o Polskiej Macierzy Szkolnej, Warszawa 2016, s. 269.

${ }^{48}$ AAN, zespół: MSZ, sygn. 10752, Dopełnienie do Raport wicekonsula Tadeusza Kijeńskiego pt. Szkolnictwo polskie na Bukowinie na tle szkolnictwa mniejszościowego, Czerniowce dn. 28.03.1930, k. 68.

49 W. Sworakowski, Polskie szkolnictwo prywatne..., s. 74. 
Z wymienionych form kształcenia korzystało 674 dzieci $^{50}$. Warto dodać, że w latach 1929-1931 szkoły prowadzone przez PSMwR mieściły się w miejscowościach: Bojany, Czerniowce, Hliboka, Kiszyniów, Lupeni, Łużany, Panka, Rarańcza, Sadagóra, Stara Huta, Terebleszty ${ }^{51}$. Z danych archiwalnych wynika, że również w Bukareszcie istniała „szkółka dla dzieci” mniejszości polskiej ${ }^{52}$. Niemniej zapotrzebowanie na szkoły polskie w Wielkiej Rumunii było spore. Na mapie Rumunii było 40 miejscowości, w których liczba dzieci polskich w wieku szkolnym przekraczała 30 (a w przypadku szkół prywatnych w klasie wystarczyło 20 uczniów). W czerwcu 1929 r. do powszechnych szkół rumuńskich uczęszczało 2499 dzieci Polonii ${ }^{53}$. W roku szkolnym 1930/31 w miejscowościach zamieszkałych przez Polaków w Królestwie Rumunii uczyło się zaledwie 20\% polskich dzieci ${ }^{54}$. Działalność PSMwR była subsydiowana przez polskie Ministerstwo Spraw Zagranicznych ${ }^{55}$. Przestała istnieć po czterech latach funkcjonowania. Jednym z powodów zaprzestania działalności PMSwR były zarzuty samych nauczycieli skupionych wokół tej instytucji. W oświadczeniu sporządzonym 25 czerwca 1931 r. czytamy: Nauczyciele PMS [...] stwierdzaja, że dla rozwoju szkół polskich w Rumunji jest wysoce szkodliwe: uzależnienie ich od spraw partyjno-politycznych, mieszanie się czynników niefachowych do spraw czysto pedagogiczno-szkolnych, nie wypłacanie $w$ pore poborów nauczycielskich i używanie pieniędzy przeznaczonych na ten cel na inne wydatki. Wobec powyższego grono nauczycielskie szkót polskich $w$ Rumunji oświadcza, że: 1) w tych warunkach praca jest niemożliwa $[\ldots]^{56}$. Zarzuty stawiano Szymonowiczowi, który wdał się w działalność polityczną ${ }^{57}$.

Po likwidacji Polskiej Macierzy Szkolnej w Rumunii powołano Polski Związek Szkolny w Rumuni (PZSwR) z siedzibą w Czerniowcach. 27 czerwca 1931 r. na zebraniu założycielskim zorganizowanym w Bursie im. Adama Mickiewicza w Czerniowcach wybrano zarząd Związku. Na jego czele stanął dr Aleksander Skibiniewski z Hliboki, wiceprezesem został ks. Mieczysław Gieszczykiewicz, skarbnikiem Józef Aleksantowicz, książkowym dyr. Władysław Sedelmeyer, sekretarzem Franciszek Bohosiewicz oraz

${ }^{50}$ AAN, zespół: MSZ, sygn. 10752, Opracowanie wicekonsula Tadeusza Kijeńskiego pt. Szkolnictwo polskie na Bukowinie na tle szkolnictwa mniejszościowego, Czerniowce dn. 24.01.1930, k. 18.

51 T. Dubicki, Rumunia, w: Encyklopedia polskiej emigracji i polonii, (red.) K. Dopierała, t. IV, Toruń 2005, s. 301-302.

52 AAN, zespół: MSZ, sygn. 10752, Pismo Konsula Rzeczypospolitej Polskiej do Ministerstwa Spraw Zagranicznych w Warszawie z dnia 18 marca 1928 roku w sprawie szkolnictwa polskiego w Rumunii, k. 144-145.

${ }^{53}$ AAN, zespół: MSZ, sygn. 10752, Dopełnienie do Raport wicekonsula Tadeusza Kijeńskiego pt. Szkolnictwo polskie na Bukowinie na tle szkolnictwa mniejszościowego, Czerniowce dn. 28.03.1930, k. 70.

54 W. Sworakowski, Polskie szkolnictwo prywatne..., s. 77.

${ }^{55}$ K. Dopierała, op. cit., s. 661.

56 [b. a.], Stowa prawdy Nowe drogi szkolnictwa polskiego, „Polak w Rumunii” z dnia 5 lipca 1931, nr 25.

${ }^{57}$ Confer m.in.: P. Gołdyn, Konflikt Polskiej Macierzy szkolnej w Rumunii z konsulem Mieczysławem Grabińskim, w: Związki polsko-rumuńskie w historii i kulturze / Legături istorice și culturale polono-române, opracowanie redakcyjne K. Stempel-Gancarczyk, E. Wieruszewska-Calistru, Suceava 2018, s. 187-203. 
członkowie: Tadeusz Neumajer, Karol Sass, Tadeusz Kossowski, Józefa Mitelska i dwóch reprezentantów włościan. Zadaniem PZSwR było organizowanie i utrzymanie szkolnictwa polskiego w Rumunii, działalność pozaszkolna oraz reprezentowanie polskich interesów oświatowych wobec rumuńskich władz ${ }^{58}$. W Królestwie Rumunii Polacy stanowili najmniejszą liczebnie mniejszość narodową, dlatego też musieli zabiegać o własne szkolnictwo na jego terytorium.

Do walki o polską szkołę w Rumunii przyczynili się też sami nauczyciele. Za ich sprawą w dniach 19-20 czerwca 1932 r. w Czerniowcach odbył się I Zjazd Nauczycielstwa Polskiego w Rumunii ${ }^{59}$. Zjazd zgromadził liczne grono nauczycieli z polskich szkół prywatnych oraz państwowych. Wśród obecnych znaleźli się też przedstawiciele Związku nauczycielstwa rumuńskiego w osobach panów Simionovici i Reus. Delegatami związkowymi z Polski byli Jan Balicki z Lwowa i Michał Markowski ze Śniatynia. Ze Śniatynia przybyła też grupa nauczycieli wraz z inspektorem szkolnym Mądrym. Dyskusji nad unormowaniem nauki języka polskiego w szkołach prywatnych i państwowych w Rumunii oraz posłannictwa w zakresie oświaty pozaszkolnej przysłuchiwało się 58 czynnych nauczycieli. Obradom przewodniczył Jan Rajner, nauczyciel ze szkoły w Baniłowie nad Czeremoszem. Nie zabrakło też członków PZSwR oraz duchowieństwa. Owocem Zjazdu było przyjęcie Rezolucji oraz przygotowanie dwóch depesz, jednej do Rady Organizacyjnej Polaków z Zagranicy w Warszawie, a drugiej do Ministerstwa Oświaty w Bukareszcie. Na łamach prasy podkreślano: $W$ ostatecznym określeniu wyników Zjazdu musimy stwierdzić, że z cata pewnościa nie zawiódt on oczekiwań całego spoleczeństwa, że dat całkowicie pozytywne rezultaty ${ }^{60}$.

PZSwR, poza centralą w Czerniowcach, miał też swoje oddziały terenowe. Zajmowały się one przede wszystkim opieką nad daną szkołą, dbaniem o porządek, dostarczeniem opału i niektórych potrzebnych pomocy szkolnych ${ }^{61}$.

W roku szkolnym 1934/35 w Królestwie Rumunii nie było szkół publicznych dla Polonii, co potwierdza opracowanie pt. Polacy $w$ Rumunii znajdujące się w zbiorach Centralnego Archiwum Wojskowego w Warszawie ${ }^{62}$. Ponadto, w tym też okresie, rumuńskie Ministerstwo Oświaty, Wyznań i Sztuki stosowało sankcje wobec polskich nauczycieli. Za niezłożenie egzaminu z języka rumuńskiego dla nauczycieli mniejszościowych grożono zwolnieniem z pracy. Taki los spotkał np. nauczyciela prowizorycznego Leopol-

${ }^{58}$ [b. a.], Stowa prawdy....

${ }^{59}$ [b. a.], Nauczycielstwo na szańcach oświaty i kultury polskiej. Sprawozdanie z przebiegu obrad Zjazdu Nauczycielstwa Polskiego, ,Polak w Rumunii” 1932, nr 76 z dn. 26 czerwca, s. 1-2.

60 Ibidem, s. 2.

${ }^{61}$ AAN, zespół: Opieka polska nad Polakami na Obczyźnie, sygn. 87, Wycinki prasowe. R., Kącik nauczycielski. Rozmowa o szkolnictwie polskim na Bukowinie, wydanie z 31 grudnia 1933 roku, k. 8.

62 Vide: W. Rezmer, Polacy na Bukowinie w latach 30. XX wieku w świetle materiałów Oddziału II Sztabu Głównego Wojska Polskiego, w: Historia i dzień dzisiejszy w relacji polsko-rumuńskich, opracowanie redakcyjne i korekta tekstów polskich K. Stempel-Gancarczyk, E. Wieruszewska-Calistru, Suceava 2017, s. 58. 
da Wirtha ${ }^{63}$, wcześniej wyznaczonego przez władze rumuńskie na kierownika szkoły rumuńskiej w Pleszy ${ }^{64}$. Ponadto profesorom zabroniono używania innego języka niż rumuński zarówno w szkołach, jak i na ulicach Wielkiej Rumunii. Wobec nieprzychylności władz rumuńskich do szkolnictwa nierumuńskiego ${ }^{65}$, PZSwR podejmował próby zaprowadzenia nauki języka polskiego jako współwykładowego w szkołach powszechnych we wszystkich miejscowościach na Bukowinie, gdzie liczba dzieci w wieku 7-16 lat wynosiła ponad 100 osób. W pierwszej kolejności miały to być miejscowości Nowy Sołoniec i Bujany, następnie Waszkowce, Wyżnica, Storożyniec, Tereblesti, Stanowce, Kocmań, Baniłów, Cuciurul-Mie, Zastawna, Lehuceni-Teutului, w czterech szkołach powszechnych w Czernowcach. Ostatecznie inicjatywy te zostały zablokowane przez administrację rumuńską ${ }^{66}$. Jednak potrzeba kształcenia dzieci polskich w Królestwie Rumunii była ogromna. Podkreślał to „Kurier Polski” w 1937 r., pisząc: Oto na około 12 tys. dzieci polskich $w$ Rumunii, ledwie 2 tys. uczęszcza do szkoty polskiej lub $w$ rozmaitej formie pobiera lekcje ojczystego języka ${ }^{67}$.

Sytuacja polskich dzieci w Królestwie Rumunii, jak wynika ze sprawozdań PZSwR, uległa poprawie w roku szkolnym 1937/38. Wtedy to prawa publiczności uzyskała polska 6-klasowa szkoła powszechna w Czerniowcach oraz polska szkoła powszechna w Bielcach. Wcześniej takie prawo pozyskała Polska Szkoła Powszechna PZSwR w Lupeni (Siedmiogród). Ponadto PZSwR wniósł podania o otwarcie nowych szkół prywatnych w miejscowościach: Bułaj, Piotrowce-Arszyca, Pojana Mikuli, Nowy Sołoniec ${ }^{68}$.

Dnia 19 listopada 1938 r. PZSwR uzyskał zgodę rumuńskiego Ministerstwa Oświaty na autoryzację nauczania języka polskiego w szkołach państwowych. Autoryzacją objęto szkoły w 17 miejscowościach na Bukowinie oraz $1 \mathrm{w}$ Besarabii. Na podstawie autoryzacji nauczyciele uczyli języka polskiego w wymiarze 2-3 razy tygodniowo każde dziecko ${ }^{69}$.

${ }^{63}$ Po interwencji ludności Pleszy oraz pertraktacji PZSwR nauczyciela L. Wirth'a przeniesiono do szkoły polskiej prywatnej w Rarańczy. Natomiast w rumuńskiej szkole państwowej w Pleszy władze szkolne zezwoliły na naukę 2 godz. tygodniowo języka polskiego w każdej klasie. Nauczanie prowadził nauczyciel Władysław Sidak dojeżdżający ze szkoły w Nowym Sołońcu, AAN, zespół: Ministerstwo Spraw Zagranicznych, sygn. 6422, Konsulat Rzeczypospolitej Polskiej ws. zwolnienia nauczyciela-Polaka w Pleszy do Ministerstwa Spraw Zagranicznych w Warszawie. Pismo z dn. 7 lutego 1936 r., k. 43-45.

${ }^{64}$ AAN, zespół: MSZ, sygn. 6422, Rewizor szkolny w Kimpólungu, Pismo z dn.26 listopada 1935, Thumaczenie z rumuńskiego. odpis. k. 41.

${ }^{65}$ (ZJ), Dzieci polskie w Rumunii pozbawione języka ojczystego, ,Ilustrowany Kuryer Codzienny” z dnia 4 lipca 1935, nr 183, s. 8.

${ }^{66}$ AAN, zespół: Opieka polska nad Polakami na Obczyźnie, sygn. 87, Wycinki prasowe. [bez autora], Dzieci polskie w Rumunji pozbawione języka ojczystego, „Ilustrowany Kuryer Codzienny”, z 4 lipca 1935, k. 13.

${ }^{67}$ AAN, zespół: Opieka polska nad Polakami na Obczyźnie, sygn. 87, Wycinki prasowe. [bez autora] Nasza największa troska, „Kurier Polski w Rumunii”, z dn. 11 kwietnia 1937, nr 195, s. 3, [bez pag.].

${ }^{68}$ AAN, zespół: MSZ, sygn.10553, Sprawozdanie Polskiego Związku Szkolnego w Czerniowcach za czas od 30.I.1938 do 1.IV.1939, k. 44.

${ }^{69}$ AAN, zespół: MSZ, sygn.10553, Sprawozdanie Polskiego Związku Szkolnego w Czerniowcach za czas od 30.I.1938 do 1.IV.1939, k. 45. 
Natomiast w trzech szkołach nie objętych autoryzacją (Kocmań, Zastawna, Glodeni) prowadzone były prywatne kursy języka polskiego. Podobne kursy w takich miejscowościach jak: Pohorlăuţi, Vrânceni, Zviniace, Cuciurul-Mie i Mihoveni, organizowali księża Polacy,

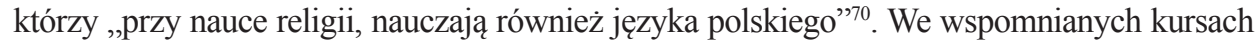
pracowali polscy nauczyciele zatrudniani i wynagradzani przez PZSwR. Tylko polska szkoła z prawem publiczności w Kiszyniowie oraz kursy języka polskiego w Ploesti, w Chocim i w Soroka to przykład inicjatywy społeczności lokalnej czasami nawet bezinteresownej ${ }^{71}$.

Stan szkolnictwa polskiego w Królestwie Rumunii na dzień 1 kwietnia 1939 przedstawiał się następująco: 1 prywatne polskie gimnazjum PZSwR w Czerniowcach, 7 polskich szkół powszechnych PZSwR (Czerniowce, Hliboka, Lupeni, Łużany, Bielce, Rarańcza, Panka), 3 polskie prywatne szkoły parafialne (Bojany, Sadagóra, Stara-Huta) i 2 przedszkola (Czerniowce, Sadagóra). Ogółem do szkół i przedszkoli uczęszczało 825 uczniów. Ponadto prowadzonych było 11 prywatnych kursów języka polskiego dla 284 dzieci $^{72}$. W szkołach państwowych lekcje języka polskiego pobierało 1399 uczniów. Ogółem, w analizowanym okresie, na terenie Rumunii było 2508 dzieci uczących się po polsku ${ }^{73}$. Do tego zestawienia należy też dołączyć formy działalności pozalekcyjnej i pozaszkolnej, tj. świetlice młodzieżowe, drużyny harcerskie, drużyny sportowe oraz chóry ${ }^{74}$. Wspomnieć również należy działalność Zgromadzenia Sióstr św. Feliksa z Kantalicjo, sprowadzającą się do prowadzenia czerniowieckiej ochronki i sierocińca ${ }^{75}$. Podsumowując, warto dodać, że nadzór nad szkolnictwem polskim prywatnym oraz w szkołach państwowych w Rumunii sprawował inspektor Wacław Sanicki ${ }^{76}$, który był jednocześnie nauczycielem języka polskiego i chemii w Polskim Prywatnym Gimnazjum PZSwR w Czerniowcach. Wszelkie formy działalności oświatowej prowadzone były w Domach Polskich, w budynkach Polskiej Kasy Reifeisena, w domach parafialnych lub lokalach wynajmowanych i opłacanych przez PZSwR ${ }^{77}$.

${ }^{70}$ AAN, zespół: MSZ, sygn.10553, Sprawozdanie Polskiego Związku Szkolnego w Czerniowcach za czas od 30 I 1938 do 1 IV 1939, k. 46.

71 AAN, zespół: MSZ, sygn.10553, Sprawozdanie Polskiego Związku Szkolnego w Czerniowcach za czas od 30 I 1938 do 1 IV 1939, k. 46.

72 AAN, zespół: MSZ, sygn.10553, Sprawozdanie Polskiego Związku Szkolnego w Czerniowcach za czas od 30 I 1938 do 1 IV 1939, k. 46-47.

73 AAN, zespół: MSZ, sygn.10553, Sprawozdanie Polskiego Związku Szkolnego w Czerniowcach za czas od 30 I 1938 do 1 IV 1939, k. 51.

74 AAN, zespół: MSZ, sygn.10553, Sprawozdanie Polskiego Związku Szkolnego w Czerniowcach za czas od 30 I 1938 do 1 IV 1939, k. 55.

75 P. Gołdyn, Działalność społeczno-wychowawcza sióstr felicjanek w Czerniowcach (1887-1945) /Activitatea socio-educativă a surorilor feliciene în Cenăuţi (1887-1945), w: W kręgu polsko-rumuńskiej wspótpracy oświatowej w pierwszej połowie XX wieku. Wybrane aspekty /Aspecte ale colaborării polono-române în domeniul educaţiei în prima jumătate a secolului al. XX-leal, Poznań - Kalisz 2017, s. 93-105.

${ }^{76}$ AAN, zespół: MSZ, sygn.10553, Sprawozdanie Polskiego Związku Szkolnego w Czerniowcach za czas od 30 I 1938 do 1 IV 1939, k. 52.

77 AAN, zespół: MSZ, sygn.10553, Sprawozdanie Polskiego Związku Szkolnego w Czerniowcach za czas od 30 I 1938 do 1 IV 1939, k. 47-49. 
Odrębny okres w historii szkolnictwa polskiego w Rumunii zajmują lata 1939-1945, kiedy to funkcjonowało szkolnictwo uchodźcze. Szczególną rolę w jego powstawaniu odegrał historyk wychowania dr Łukasz Kurdybacha. Zagadnienie to autorka uczyniła przedmiotem zainteresowań w opracowaniu pt. Działalność historyka oświaty Łukasza Kurdybachy w Królestwie Rumunii w latach 1939-194078. Inne są też losy szkolnictwa polonijnego na terenie Besarabii, która w 1940 r. znalazła się w granicach ZSRR, a obecnie znajduje się w Republice Mołdawii.

\section{Podsumowanie}

W prezentowanym artykule przybliżono dzieje szkolnictwa dla mniejszości polskiej na terenie dzisiejszej Rumunii w okresie od początków XIX w. do 1939 r. Wraz z napływem nowej fali emigracji polskiej w okresie porozbiorowym rozpoczął się etap tworzenia polskich szkół. Początkowo szkoły bądź tylko lekcje języka polskiego organizowano na terenie Bukowiny. Do I wojny światowej przy wsparciu organizacji społeczno-światowych tj. Towarzystwo Czytelni Ludowych oraz Towarzystwo Polskie Bratniej Pomocy i Czytelni Polskiej powstały 23 szkoły prywatne na Bukowinie. W 1918 r. po zjednoczeniu Rumunii, w jej obszar weszły Bukowina, Besarabia, Siedmiogród oraz Banat. Szkolnictwo mniejszości narodowych zostało zrumunizowane. Likwidowano naukę języka polskiego w szkołach państwowych. Rozwiązaniem dla Polonii w Wielkiej Rumunii stała się Ustawa o nauce prywatnej z 1925 r., która umożliwiła podmiotem prawnym organizowanie i prowadzenie szkół polskich. Obowiązek otwierania szkół polskich przejęły na siebie najpierw gminy polskie, które głównie skupione były w Besarabii, następnie towarzystwo oświatowe Polska Macierz Szkolna w Rumunii. Po jego likwidacji w 1931 r. prowadzeniem szkół polskich w Królestwie Rumunii zajął się Polski Związek Szkolny w Rumunii z siedzibą w Czerniowcach. W ostatnim kwartale roku szkolnego 1938/39 Polacy w Królestwie Rumunii utrzymywali prywatne polskie instytucje oświatowe takie, jak: jedno gimnazjum, 10 szkół powszechnych i 2 przedszkola oraz prywatne kursy języka polskiego. Prowadzili też różne formy działalności pozalekcyjnej i pozaszkolnej.

W okresie od początków XIX w. do 1939 r. Polacy tworzyli w Rumunii głównie szkoły ogólnokształcące typu powszechnego i średniego oraz ochronki. Podejmowali próby wprowadzenia nauki języka polskiego do zakładów kształcenia nauczycieli. Zakładali własne towarzystwa społeczno-oświatowe oraz Domy Polskie, w których rozwijali szeroką działalność oświatowo-kulturalną.

Wybuch II wojny światowej i napływ polskich obywateli wojskowych, jak i cywilnych do Rumunii otworzył nową kartę w historii szkolnictwa polonijnego i uchodźczego w tym kraju.

${ }_{78}$ M. Radziszewska, Działalność historyka oświaty Lukasza Kurdybachy w Królestwie Rumunii w latach 1939-1940, w: Polska i Rumunia. Wspólnie - obok - blisko, oprac. red. i korekta tekstów polskich K. StempelGancarczyk, E. Wieruszewska-Calistru, Suceava, 2015, s. 188-200. 


\section{Bibliografia}

\section{Źródła archiwalne}

Archiwum Akt Nowych w Warszawie, zespół: Ministerstwo Spraw Zagranicznych, sygn. 6422, 10533, 10752 zespół: Opieka polska nad Polakami na Obczyźnie, sygn. 87.

Prasa

„Ilustrowany Kuryer Codzienny” (1935).

„Nowa Reforma” (1906).

„Polak w Rumunii” (1931-1932).

\section{Opracowania}

Biedrzycki E., Historia Polaków na Bukowinie, Warszawa-Kraków 1973.

Cioroianu A., Piękne początki, w: Lacińska wyspa. Antologia rumuńskiej literatury faktu. Wybór, opracowanie i komentarze Bogumił Luft, Warszawa 2018, s. 16.

Ćwiek W., Przeszłość Towarzystwa polskiego bratniej pomocy i Czytelni polskiej, Czerniowce 1995.

Demel J., Historia Rumunii, wyd. II poprawione i uzupełnione, Wrocław-Warszawa-Kraków-Gdańsk-Łódź 1986.

Dopierała K., Społeczność polska na Bałkanach Rumunia, Butgaria, Jugosławia, w: Polonia w Europie, (red.) B. Szydłowska-Ceglowa, Poznań 1992.

Dubicki T., Rumunia, w: Encyklopedia polskiej emigracji i Polonii, (red.) K. Dopierała, t. IV, Toruń 2005.

Gołdyn P., Działalność społeczno-wychowawcza sióstr felicjanek w Czerniowcach (1887-1945) / Activitatea socio-educativă a surorilor feliciene in Cenăuţi (1887-1945), w: W kręgu polsko-rumuńskiej wspótpracy oświatowej w pierwszej połowie XX wieku. Wybrane aspekty /Aspecte ale colaborării polono-române în domeniul educației în prima jumătate a secolului al. XX-leal, Poznań - Kalisz 2017.

Gołdyn P., Konflikt Polskiej Macierzy szkolnej w Rumunii z konsulem Mieczysławem Grabińskim, w: Związki polsko-rumuńskie w historii i kulturze / Legături istorice și culturale polono-române, opracowanie redakcyjne K. Stempel-Gancarczyk, E. Wieruszewska-Calistru, Suceava 2018.

Gołdyn P., Wizyta ministra oświaty Rumunii Constantina Angelescu w Polsce w 1937 r. w świetle ówczesnych doniesień prasowych, w: W kręgu polsko-rumuńskiej wspótpracy oświatowej w pierwszej połowie XX wieku. Wybrane aspekty /Aspecte ale colaborării polono-române în domeniul educaţiei în prima jumătate a secolului al. XX-leal, Poznań-Kalisz 2017.

Markiewicz H., Rzecz o Polskiej Macierzy Szkolnej, Warszawa 2016.

Nistor I., Istoria Bucovinei, București 1991.

Nowak K., Problemy szkolnictwa polskiego w Rumunii oraz Mołdawii dawniej i współcześnie, „Rocznik Stowarzyszenia Naukowców Polaków Litwy”, 2017, t. 17. 
Nowak K.., Polskie życie organizacyjne w Rumunii do 1989 roku, w: Zwiąek Polaków w Rumunii 1990-2010, opracowanie i korekta S. Iachimovschi, E. Wieruszewska-Calistru, Suceava 2010.

Radziszewska M., Działalność historyka oświaty Łukasza Kurdybachy w Królestwie Rumunii w latach 1939-1940, w: Polska i Rumunia. Wspólnie - obok-blisko, oprac. red. i korekta tekstów polskich K. Stempel-Gancarczyk, E. Wieruszewska-Calistru, Suceava 2015.

Radziszewska M., Stan prywatnego szkolnictwa polskiego $w$ Królestwie Rumunii $i$ w rejencji olsztyńskiej Prus Wschodnich na kanwie wizyty rumuńskiego ministra oświaty Constantina Angelescu w Polsce w 1937 roku, w: Historia i dzień dzisiejszy w relacji polsko-rumuńskich, opracowanie redakcyjne i korekta tekstów polskich K. Stempel-Gancarczyk, E. WieruszewskaCalistru, Suceava 2017.

Radziszewska M., Wyjazd studyjny polskich historyków wychowania do Rumunii, „Biuletyn Historii Wychowania" 2017, nr 37.

Rezmer W., Polacy na Bukowinie w latach 30. XX wieku w świetle materiałów Oddziału II Sztabu Głównego Wojska Polskiego, w: Historia i dzień dzisiejszy w relacji polsko-rumuńskich, opracowanie redakcyjne i korekta tekstów polskich K. Stempel-Gancarczyk, E. Wieruszewska-Calistru, Suceava 2017.

Salmonowicz S., Podstawy prawne funkcjonowania Komisji Edukacji Narodowej, „Rozprawy z Dziejów Oświaty",1980, nr 23.

Smólski G., Polacy na Bukowinie, „Nowa Reforma” 1906, nr 234 z 14 października, s. 1.

Stępowski M., Towarzystwo Szkoły Ludowej: jak powstało, co zrobiło i do czego dąży: w 20-ta rocznice powstania Towarzystwa, Kraków 1911.

Sworakowski W., Mniejszości narodowe w Rumunji wobec programu rządowego, „Sprawy Narodowościowe" 1930, nr 5-6.

Sworakowski W., Polskie szkolnictwo prywatne w Rumunii, „Sprawy Narodowościowe” 1931, nr 1.

Sylburska A., Kwestia mniejszości węgierskiej w Czechostowacji, Rumunii i Jugosławii w okresie międzywojennym na łamach „Spraw Narodowościowych” (1927-1939), „Acta Universitatis Lodziensis Folia Historica” 2014, nr 92.

Szewczyk A., Jest takie miejsce ... Kaczyka na Bukowinie, „Wiadomości Bocheńskie” 2015, nr 4. Zelionca A-E., Nowy Sołoniec. Dzieje wsi i parafii, Suceava 2014.

Zelionca A-e., Plesza. Dzieje wsi i parafi, Suceava 2016.

\section{Materiały elektroniczne}

Lewandowska D., C. K. Ministerstwo Wyznań i Oświaty 1848-1918, Archiwum Główne Akt Dawnych w Warszawie, https://www.archivesportaleurope.net/ead-display/-/ead/pl/aicode/PL-1/ type/fa/id/PL-1-304_SLASH_0;jsessionid=C298A68029531A0119BCC1A9E3EBCFFD 